\title{
Selection of Recommended Engineering Geological Parameters of Soil Dam Foundation in Suki Kinari Hydropower Project in Pakistan
}

\author{
Dong Cheng Shan", a, Yuan Yan Chao ${ }^{1, b}$, Zhao Lin ${ }^{1, ~ c}$, Fang Hai Yan ${ }^{1, d}$, Yang \\ Zheng Quan², e
}

\author{
${ }^{1}$ China Water Resources Beifang Investigation, Design and Research Co. Ltd, No.60, Dongting \\ Road, Hexi District, Tianjin, P. R. China (300222) \\ ${ }^{2}$ Department of Geotechnical Engineering, IWHR, No.20, West Chegongzhuang Road, Haidian \\ District, Beijing, P.R. China (100048) \\ aspikedong@qq.com, b283914255@qq.com, c519297646@qq.com, d305167817@qq.com, \\ e28508030@qq.com
}

Keywords: Suki Kinari Hydropower Project, Deep-thickness overburden, Laboratory test, In-situ test, Engineering analogy, Soil dam foundation, Recommended Engineering Geological Parameter Abstract: For the dams built on deep-thickness overburden, selection of engineering geological parameters has outstanding importance, which directly affect the design and construction of dam. In the study, the Suki Kinari Hydropower project in Pakistan is discussed as an example, considering the characteristics of disorder composition, and unapparent regularity of overburden, combining with the impractical condition of taking undisturbed samples, several methods are adopted comprehensively during investigation, which help engineers to solve the engineering problem.

\section{Introduction}

In recent years, more and more dams are built on deep-thickness overburden. Since most of the overburden on riverbed consists of boulders, cobbles, gravels and sand, and undisturbed samples are very difficult to take for mechanical tests, which increases the difficulty of selection of engineering geological parameters. The planned Suki Kinari Hydropower project is located in Pakistan, and the dam will be built on the Kunhar river, according to the investigation results, the overburden on riverbed is very deep (maximum depth exposed by borehole is $118 \mathrm{~m}$ ), with complicated origin and disorder composition. Base on soil test results, combining with in-situ tests, the basic physical indexes could be obtained, meanwhile the mechanical index could be calculated by in-situ test results, furthermore by engineering analogy with similar hydropower projects, the recommended engineering geological parameters could be provided finally.

\section{General Geology}

The planned dam will be built across the Kunar river on Quaternary overburden. According to the drilling data, the riverbed overburden could be approximately divided into four layers from top to 
the bottom. According to the design scheme, since the layer (1) is very thin, and its engineering properties is poor, it shall be excavated. so that only layer (2), (3), and (4) will be discussed in this study.

The layer (2) is alluvial and proluvial deposits of Quaternary Holocene $\left(\mathrm{Q}_{4}{ }^{2 \mathrm{al}+\mathrm{pl}}\right)$, mainly boulders, cobbles and gravels, clayey silt with gravel locally. Contains approximately 50 to $60 \%$ boulders and cobbles, approximately 20 to $30 \%$ gravels, with small amount of medium coarse sand locally, medium dense to dense, filled with fine sand partly.

The layer (3) is alluvial and lacustrine deposits of Quaternary Holocene $\left(\mathrm{Q}_{4}{ }^{\mathrm{a}+\mathrm{l}}\right)$, mainly fine silty sand, medium coarse sands and medium fine sand, with gravels, clayey silt and silty clay in some parts, grayish black, medium dense to dense, with odor.

The layer (4) is alluvial and glacial deposits of Quaternary Upper Pleistocene $\left(\mathrm{Q}_{3}{ }^{\mathrm{al}+\mathrm{fgl}}\right)$, mainly comprised by boulders, cobbles and gravels, sub-angular. Contains more than $80 \%$ of boulders, cobbles and gravels, with silty clay or clayey silt with gravel, dense.

\section{Tests conducted}

\section{(1) Sieve analysis}

In order to confirm the grain size distribution, several sieve analysis tests were conducted on both of disturbed/Undisturbed samples. According to the test results, the grain size distribution curves (average value) is shown in Fig. 1.

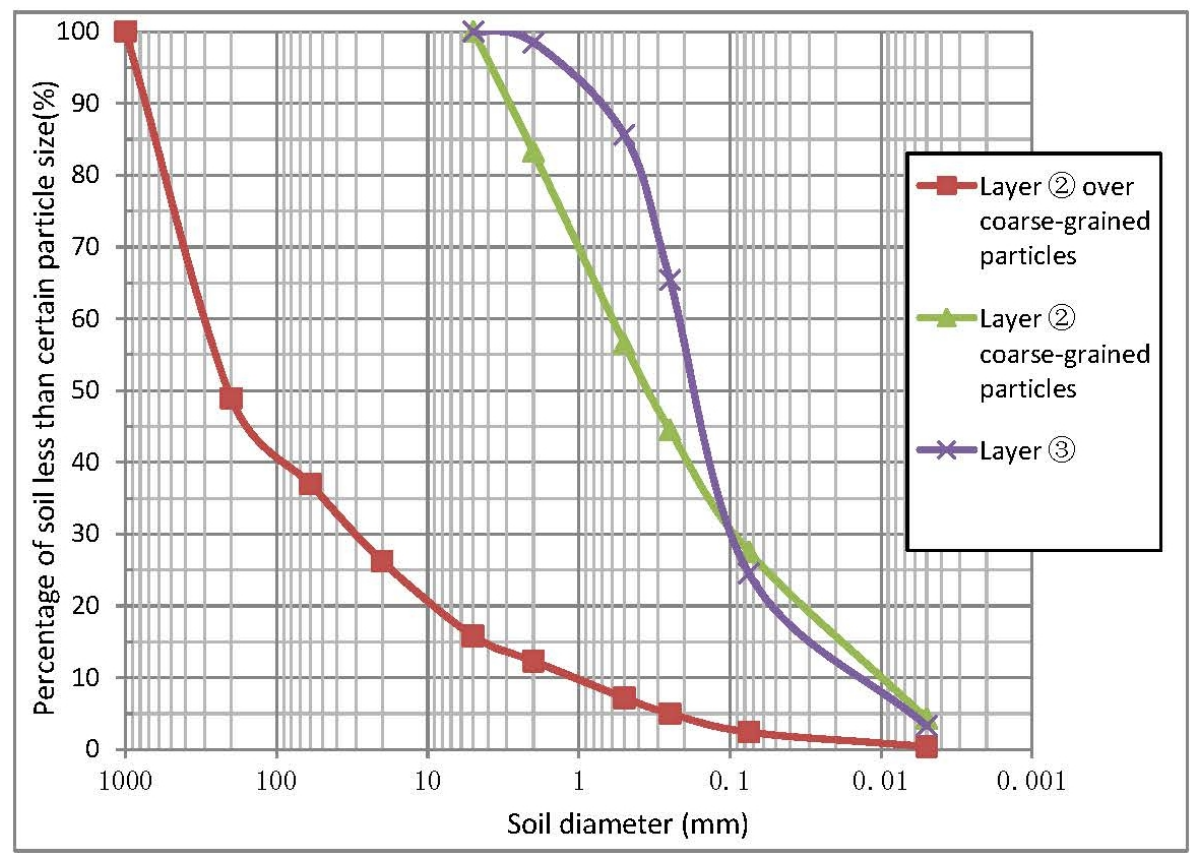

Fig. 1 The grain size distribution (average value) curves

(2) Relative density test

In order to check the compactness degree of overburden, relative density tests were conducted in layer (2) Layer (3) respectively, and the test results are as following: layer (2): the relative density ranges from 0.29 to 0.43 , average 0.34 , shows the layer is loose. Layer (3): the relative density ranges from 0.47 to 0.81 , average 0.63 . 


\section{(3) In-situ tests}

During the investigation, the heavy conical dynamic penetration test (DPT) was carried out on the coarse-grained soil, and standard penetration test (SPT) was carried out in the sandy soil. Rod length modification on tests conducted is processed as followings: within $20 \mathrm{~m}$, we follow the standard in operation [1], while deeper than $20 \mathrm{~m}$ are referenced to recent research results [2].

1) Dynamic penetration test (DPT)

According to the standard value of DPT, except sandy gravel in layer (3), blow counts in the rest of the soil ranges from 10 to 30, and after rod length modification, the average value in most soil layers are between 10 to 20. In the layer (3), the standard measured value of blow counts of N63.5' in sandy soil layer which dominates the layer (3) is 15.8 , while after rod length modification coefficient is 9.6 .

\section{2) Standard penetration test (SPT)}

SPT are conducted in the layer (3). The test results show that measured blow counts range from 13 to 55 , average 32.8 , while after rod correction range from 7.5 to 31.4 , average 18.9 , and the standard value of measured and corrected counts are 29.5 and 17.0 respectively.

The test result indicates that the layers mainly are medium dense to highly dense, parts are slightly dense, which show that uniformity of the layer is poor.

(4) Permeability test

In order to check the permeability of foundation soil, water injection tests and pumping tests are conducted in layer (2), (3), and (4).

In summary, the basic physical properties of foundation soil could be confirmed by the above-mentioned tests, and the test results are listed in Table 1.

Table 1 List of basic physical properties of soil strata

\begin{tabular}{|c|c|c|c|c|}
\hline Strata & Grain grading index & Density & $\begin{array}{l}\text { Water injection test } \\
\qquad(\mathrm{cm} / \mathrm{s})\end{array}$ & $\begin{array}{l}\text { Pumping test } \\
\qquad(\mathrm{cm} / \mathrm{s})\end{array}$ \\
\hline \multirow[b]{2}{*}{ Layer (2) } & \multirow{2}{*}{$\begin{array}{c}\text { particles greater } \\
\text { than gravels } 63.4 \%, \\
\text { gravel } 36.6 \%, \text { sand } \\
9.8 \% \text {, silt } 2 \%, \text { and } \\
\text { clay } 0.2 \text { to } 0.8 \%, \\
\text { average } 0.4 \% .\end{array}$} & \multirow{2}{*}{$\begin{array}{c}\text { Density of giant-grained } \\
\text { soil: } 1.75 \text { to } 1.94 \mathrm{~g} / \mathrm{cm}^{3}, \\
\text { average } 1.91 \mathrm{~g} / \mathrm{cm}^{3}, \text { dry } \\
\text { density } 1.71 \text { to } 1.86 \\
\mathrm{~g} / \mathrm{cm}^{3}, \text { average } \\
1.82 \mathrm{~g} / \mathrm{cm}^{3}\end{array}$} & $\begin{array}{c}\text { coarse-grained soil: } \\
\text { 9.85E-05 to } 1.21 \mathrm{E}-02, \\
\text { average } 3.34 \mathrm{E}-03\end{array}$ & \multirow{2}{*}{$\begin{array}{l}8.24 \mathrm{E}-04 \\
\text { to } 1.04 \mathrm{E}-03\end{array}$} \\
\hline & & & $\begin{array}{c}\text { giant-grained soil: } \\
2.11 \mathrm{E}-04 \text { to } \\
4.26 \mathrm{E}+00, \text { average } \\
5.73 \mathrm{E}-01\end{array}$ & \\
\hline Layer (3) & $\begin{array}{c}\text { Clay content is } 0 \text { to } \\
10.2 \%, \text { average } \\
3.3 \%\end{array}$ & $\begin{array}{c}\text { Natural density: } 1.87 \text { to } \\
2.0 \mathrm{~g} / \mathrm{cm}^{3} \text {, average } \\
1.94 \mathrm{~g} / \mathrm{cm}^{3}, \text { dry density } \\
1.41 \text { to } 1.58 \mathrm{~g} / \mathrm{cm}^{3} \\
\text { average } 1.52 \mathrm{~g} / \mathrm{cm}^{3}\end{array}$ & $\begin{array}{c}3.25 \mathrm{E}-06 \text { to } 2.59 \mathrm{E}-05, \\
\text { average } 1.13 \mathrm{E}-05\end{array}$ & $\begin{array}{l}1.70 \mathrm{E}-05 \text { to } \\
4.62 \mathrm{E}-05\end{array}$ \\
\hline Layer (4) & No sample taken & No test data & $\begin{array}{c}2.96 \mathrm{E}-04 \text { to } 6.47 \mathrm{E}-03, \\
\text { average } 2.27 \mathrm{E}-03\end{array}$ & No test \\
\hline
\end{tabular}




\section{Selection of recommended engineering geological parameters}

According to the design, geological parameters are provided only for layer (2), (3) and (4), and the geological parameters are suggested mainly based on the physical index and in-situ test results, and combined with the engineering analogy.

(1) According to the result of SPT

Referenced the relevant contents in "Manual of Engineering Geology" (4th Edition) [3] to estimate soil mechanics indicators in each layer. Since the layer (3) is relatively weak, and control the engineering properties of foundation soil, only its parameters acquisition process will be explained in detail as following:

1) The shear angle $\varphi$ of the sand layer can be calculated by blow counts of SPT, and the calculating relation refers to Table 2 .

Table 2 Using the value of $\mathrm{N}$ to calculate the shear angle of sandy soil $\left(^{\circ}\right)$

\begin{tabular}{|c|c|c|c|c|c|}
\hline \multirow{2}{*}{ The researchers } & \multicolumn{5}{|c|}{$\mathrm{N}$} \\
\cline { 2 - 6 } & $<4$ & 4 to 10 & 10 to 30 & 30 to 50 & $>50$ \\
\hline Peck & $<28.5$ & 28.5 to 30 & 30 to 36 & 36 to 41 & $>41$ \\
\hline Meyerhof & $<30$ & 30 to 35 & 35 to 40 & 40 to 45 & $>45$ \\
\hline
\end{tabular}

2) According to the Webbe's empirical Equation to estimate soil modulus of deformation $E_{0}$ :

$$
\mathrm{E}_{0}=2.0+0.6 \mathrm{~N} \quad \text { Eq. } 1
$$

In the formula, the value of $\mathrm{N}$ is 29.5. By calculating, the soil deformation modulus $\mathrm{E}_{0}$ of the layer

(3) is approximately $19.7 \mathrm{MPa}$.

3) The compression modulus of the fine sand below the groundwater level can also be calculated by the following empirical Equation:

$$
\mathrm{Es}=7.1+0.49 \mathrm{~N} \quad \text { Eq. } 2
$$

In the formula, the value of $\mathrm{N}$ is 29.5. By calculating, the soil compression modulus Es of the layer (3) is approximately $21.6 \mathrm{MPa}$.

(2) According to physical indicators, combining with engineering analogy

Referenced the recommended physical mechanic parameters of similar projects with overburden foundation in China (see Table 3) [4].

To sum up, on the basis of comprehensively considering basic physical properties, in-situ test results, combining with analogy of similar projects, the main recommended engineering geological parameters of dam foundation soil are provided, which are listed in Table 4. 
Table 3 Summary of the recommended physical mechanic parameters of overburden

\begin{tabular}{|c|c|c|c|c|c|c|c|c|}
\hline \multirow{3}{*}{$\stackrel{\bar{\Delta}}{\stackrel{\bar{\alpha}}{\alpha}}$} & \multirow{3}{*}{$\frac{\bar{U}}{\stackrel{\Delta}{O}}$} & \multirow{3}{*}{ Layers and soil names } & \multirow{2}{*}{ Dry density } & \multirow{2}{*}{$\begin{array}{l}\text { Bearing } \\
\text { capacity }\end{array}$} & \multirow{2}{*}{$\left|\begin{array}{c}\text { Deformation } \\
\text { modulus } \mathrm{E}_{0}\end{array}\right|$} & \multicolumn{2}{|c|}{ Shear strength } & \multirow{2}{*}{$\begin{array}{l}\text { Permeability } \\
\text { coefficient K }\end{array}$} \\
\hline & & & & & & $\mathrm{c}$ & $\varphi$ & \\
\hline & & & $\mathrm{g} / \mathrm{cm}^{3}$ & $\mathrm{MPa}$ & $\mathrm{Mpa}$ & Mpa & $\left({ }^{\circ}\right)$ & $\mathrm{cm} / \mathrm{s}$ \\
\hline \multirow{8}{*}{ 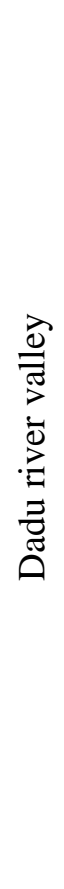 } & \multirow{3}{*}{ 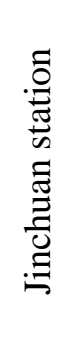 } & $\begin{array}{c}\text { (3), (1): Boulders, gravel and } \\
\text { cobbles }\end{array}$ & 2.20 to 2.30 & 0.50 to 0.55 & 40 to 50 & 0 & 30 to 32 & $\begin{array}{c}2.0 \times 10-3 \text { to } \\
5.0 \times 10^{-2}\end{array}$ \\
\hline & & $\begin{array}{l}\text { (2): Cobbles, gravels and } \\
\text { sand }\end{array}$ & 2.00 to 2.10 & 0.35 to 0.40 & 30 to 35 & 0 & 28 to 30 & $\begin{array}{c}5.0 \times 10-3 \text { to } \\
3.0 \times 10^{-2}\end{array}$ \\
\hline & & $\begin{array}{c}\text { Medium and fine sand layer } \\
\text { lenses }\end{array}$ & 1.60 to 1.80 & 0.18 to 0.20 & 15 to 20 & 0 & 20 to 23 & $\begin{array}{c}(2.0 \text { to } 5.0) \\
\times 10^{-3}\end{array}$ \\
\hline & \multirow{3}{*}{ 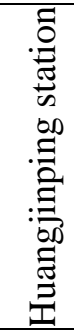 } & $\begin{array}{c}\text { (3) } \mathrm{Q}_{4}{ }^{2 \mathrm{al}} \text { : Boulders, cobbles, } \\
\text { gravels and sand }\end{array}$ & 2.10 to 2.18 & 0.50 to 0.55 & 40 to 45 & 0 & 30 to 32 & $\begin{array}{c}5.3 \times 10-2 \text { to } \\
2.0 \times 10^{-1} \\
\end{array}$ \\
\hline & & (3), (2): Sand layer & 1.50 to 1.60 & 0.12 to 0.15 & 10 to 15 & 0 & 18 to 20 & $6.9 \times 10^{-3}$ \\
\hline & & $\begin{array}{c}\text { (1) } \mathrm{Q}_{3}{ }^{\mathrm{fg}}: \text { Boulder, gravels and } \\
\text { cobbles with sand }\end{array}$ & 2.14 to 2.22 & 0.55 to 0.60 & 45 to 50 & 0 & 32 to 35 & $\begin{array}{c}(2.2 \text { to } 9.8) \\
\times 10^{-2} \\
\end{array}$ \\
\hline & 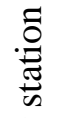 & $\begin{array}{l}\text { (3):Boulders, cobbles layer } \\
\mathrm{Q}_{4}{ }^{a \mathrm{al}}\end{array}$ & 2.20 & 0.50 to 0.60 & 55 to 65 & 0 & 30 to 31 & \\
\hline & $\underset{\Xi}{\stackrel{0}{E}}$ & $\begin{array}{c}\text { (2): } \mathrm{Q}_{4}{ }^{1} \text { silty sand and silty } \\
\text { soil }\end{array}$ & 1.70 & 0.12 to 0.15 & 10 to 13 & 0 & 18 to 20 & $\begin{array}{l}1.2 \times 10^{-3} \text { to } \\
3.4 \times 10^{-5}\end{array}$ \\
\hline
\end{tabular}

Table 4

The main recommended engineering geological parameters of soil

\begin{tabular}{|c|c|c|c|c|c|c|}
\hline \multirow[b]{2}{*}{ Stratum No. } & \multirow{2}{*}{$\begin{array}{l}\text { Natural } \\
\text { density } \\
\left(\mathrm{g} / \mathrm{cm}^{3}\right)\end{array}$} & \multicolumn{2}{|c|}{ Shear strength } & \multirow{2}{*}{$\begin{array}{l}\text { Compression } \\
\text { modulus } E_{\mathrm{s} 1-2} \\
\qquad(\mathrm{MPa})\end{array}$} & \multirow{2}{*}{$\begin{array}{c}\text { Allowable } \\
\text { bearing } \\
\text { capacity }[\mathrm{R}] \\
(\mathrm{MPa})\end{array}$} & \multirow{2}{*}{$\begin{array}{c}\text { Permeability } \\
\text { coefficient } \mathrm{K}(\mathrm{cm} / \mathrm{s})\end{array}$} \\
\hline & & $\mathrm{c}(\mathrm{MPa})$ & $\varphi\left({ }^{\circ}\right)$ & & & \\
\hline Layer (2) & 1.80 to 2.20 & 0 & 33 to 35 & 30 to 40 & 0.35 to 0.45 & $4.0 \mathrm{E}-02$ to $6.0 \mathrm{E}-03$ \\
\hline Layer (3) & 1.87 to 2.00 & 0 & 24 to 28 & 15 to 20 & 0.18 to 0.22 & $2.0 \mathrm{E}-04$ to $5.0 \mathrm{E}-05$ \\
\hline Layer (4) & 2.10 to 2.25 & 0 & 35 to 37 & 40 to 50 & 0.50 to 0.60 & $2.0 \mathrm{E}-02$ to $4.0 \mathrm{E}-03$ \\
\hline
\end{tabular}

\section{Conclusion}

The selection of engineering geological parameters of project with deep-thickness overburden is difficult due to the complicated origin and composition of overburden. Using all the methods practical shall be the best way, during engineering geological parameter selection of overburden foundation at damsite in Suki Kinari Hydropower project, laboratory tests, in-situ tests and engineering analogy are adopted comprehensively, which give us reasonable engineering geological parameters for design. Hopefully this study will be helpful for our peers in similar projects.

\section{Acknowledgements}

This work was financially supported by the National Natural Science Foundation of China (Grant No. 51509272), the special scientific research foundation of China Institute of Water Resources and Hydropower Research (GE0145B292017), the Public Service Sector R\&D Project of Ministry of 
Water Resource of China (Grant No. 201501035).

\section{References}

[1] China Architecture and Building Press. Code for investigation of geotechnical engineering (GB 50021-2001) [S] Beijing: 2001. (in Chinese)

[2] ZUO Yong-zhen, ZHAO Na. Model tests on modified coefficient of heavy dynamic penetration rod length [J]. Chinese Journal of Geotechnical Engineering, 2016, 38(Supp.2): 178 p182. (in Chinese)

[3] Manual of Engineering Geology (4th Edition) [M]. Beijing: China water resource and hydro-powder publishing house, 2007. (in Chinese)

[4] Handbook of Hydropower Engineering Geology [M]. Beijing: China water resource and hydro-powder publishing house, 2011. (in Chinese) 